\title{
BIOGRAFI PANGERAN ANTASARI
}

\author{
Nursahid \\ Email: 2010128210012@mhs.ulm.ac.id \\ Program Studi Pendidikan IPS Fakultas Keguruan dan Ilmu Pendidikan \\ Universitas Lambung Mangkurat \\ Banjarmasin
}

\begin{abstract}
Abstrak
Pangeran Antasari merupakan Raja Banjar yang lahirnya di perkirakan sekitar tahun 1790 di kampung yang dikenal Sungai Batang, Martapura. Beliau merupakan anak dari keturunan bangsawan Banjarmasin yaitu Pangeran Mas'ud(Masohot) merupakan Ayahnya dan Mas Teroda merupakan Ibunya. Walau ia adalah keturunan bangsawan ia memiliki sifat sopan santun dalam pergaulan dan watak yang rendah hati. Tujuan penulisan artikel ini adalah membahas biografi dari salah satu raja pada masa kesultanan yaitu Pangeran Antasari. Guna membahas sejarah di Indonesia yang lebih mengarah tentang Pahlawan Nasional. Dengan menggunakan metode membaca beberapa referensi.
\end{abstract}

Kata kunci: Biografi, Pahlawan, Perang Banjar, Perjuangan rakyat Banjar.

\section{PENDAHULUAN}

Kerajaan Banjar atau yang biasa dikenal sebagai masa kesultanan Banjar pada abad 18 merupakan kelanjutan dari kerajaan Daha yang dimana masa itu masyarakatnya beragama Hindu. Sedangkan kerajaan banjar merupakan kerajaan islam. Karena pada saat itu sultan suriansyah serta orang banjar masuk islam diislamkan oleh seorang penghulu yang bernama khatib dayan akibat perjanjian dengan kerajaan demak dalam meminta bantuan. Sehingga sultan suriansyah (pangeran samudera) dinobatkan sebagai raja pertama beragama islam di kesultanan banjar. Sejak saat itu pergantian dari masa kerajaan yang beragama hindu menjadi masa kerajaan islam yang bisa dikenal masa kesultanan.

Kerajaan atau yang di kenal kesultanan Banjar berdiri pada 24 September tahun 1526 dan berakhir pada tahun 1905. Kemudian raja yang menjabat pada masa kesultanan, yaitu berjumlah sebanyak 22 orang raja. Namun diantara 22 raja pada masa kesultanan Banjar tersebut hanya Pangeran Antasari yang bisa membuat yakin rakyat banjar bahwa bisa melawan belanda dan atas jasanya dalam taktik perang yang membuat belanda kewalahan atau kerugian besar dalam pertempurannya yang berlangsung 4 tahun, serta 
dengan prinsip yang dipegang teguh sampai akhir hayatnya. Sehingga beliau dianggap sebagai Pahlawan Nasional pertama di Banjar.

Sehingga nama Pangeran Antasari sangat dikenal terutama di Banjarmasin, Kalimantan Selatan. Seperti UIN Antasari, KOREM (Komando Resort Militer) 101 Antasari, jalan Antasari, Pasar Antasari, Pelabuhan Antasari dan tempat lainnya yang mencakup nama Antasari (Barjie B, 2013: 11). Namanya sangat dikenal karena tindakan kepahlawanan Pangeran Antasari dari banyak hal. Hal yang paling diingat masyarakat adalah semboyannya yaitu "haram manyarah, waja sampai ka puting". Dengan demikian pendahuluan yang dipaparkan. Tujuan penulisan artikel ini adalah membahas biografi dari salah satu raja pada masa kesultanan yaitu Pangeran Antasari. Karena guna membahas sejarah di Indonesia yang lebih mengarah tentang Pahlawan Nasional. Sehingga dapat membuat muncul rasa ingin tahu terutama bagi para pembaca (Handy, 2021: 50-51).

\section{METODE}

Metode penelitian adalah metode ilmiah dalam mendapatkan informasi yang secara khusus. Sehingga penelitian ini memakai pendekatan kualitatif yang dimana bisa mendapatkan gambaran tentang seperti apa pada saat kita melakukan penelitian. Tujuan dalam menggunakan pendekatan ini karena untuk mendeskripsikan biografi Pangeran Antasari yang dimulai dari lahirnya Pangeran Antasari, kemudian masa kecil sampai dewasanya, masa perjuangannya, dan saat terakhir Pangeran Antasari.

Peneliti melakukan teknik mengumpulkan data, kemudian menyajikan data yang didapat dan kesimpulan. Beberapa langkah dalam mengumpulkan data. Sumber yang didapat dalam mengumpulkan yaitu berjenis sumber tertulis dan sekunder yang didapatkan dari perpustakaan arsip Kalimantan Selatan. Kemudian melakukan kritik ekstern guna mengetahui tentang keaslian sumber, setelah itu menginterpretasi dari sumber yang didapat seperti membaca beberapa buku kemudian diseleksi untuk melakukan penyusunan dan menempatkan fakta dalam urutan sebab akibat. Langkah terakhir adalah menyajikan Biografi Pangeran Antasari dalam bentuk deskripsi dari hasil pengumpulan data.

\section{HASIL DAN PEMBAHASAN}




\section{A. LAHIR PANGERAN ANTASARI}

Dalam terlahirnya Pangeran Antasari atau pada masa kecilnya dikenal sebagai Gusti Inu hanya bisa ditebak (karena masih tidak bisa dipastikan) yaitu sekitar 1790 di kampung yang dikenal Sungai Batang, Martapura. Beliau merupakan anak dari keturunan bangsawan Banjarmasin yaitu Pangeran Mas'ud(Masohot) merupakan Ayahnya dan Mas Teroda merupakan Ibunya. Kemudian ada Pangeran Amir sebagai kakeknya yang terkenal karena beliau merupakan Putra mahkota Kerajaan Banjar yaitu Sultan Tahmidillah I. Beliau dibuang ke Srilangka karena tidak mau bekerja sama dengan Belanda. Sehingga beliau tutup usia di tempat tersebut (Antemas, 2004: 54).

\section{B. MASA KECIL SAMPAI DEWASA PANGERAN ANTASARI}

Pada masa kecilnya ia tidak tinggal menempati di keraton. Karena lebih banyak bergaul dan bermain dengan anak kampung Sungai Batang. Kemudian hidup sebagai rakyat jelata karena melakukan kegiatan bertani, menangkap ikan dan berburu. Namun disisi lain ia dapat belajar menggunakan senjata tajam dan pencak silat dengan beberapa pendekar yang terkenal. Walau ia adalah keturunan bangsawan ia memiliki sifat sopan santun dalam pergaulan dan watak yang rendah hati. Kemudian Pangeran Antasari merupakan orang yang tidak pendendam terhadap elit dan keturunan kesultanan Banjar yang dulunya memusuhi Pangeran Amir yang merupakan Kakeknya. Kemudian akibat pengetahuan tentang agama islam kelak akan diangkat oleh rakyat yaitu menjadi "khalifatul Mu'minin" karena sering menuntut ilmu agama islam disela waktu luang.

Di kerajaan banjar pada tahun 1787 sudah di tentukan gelar Sultan Tahmidillah II atau Panembahan Batu didapat oleh Pangeran Nata (Antemas, 2004: 55). Namun diangkat hanya sementara, karena pada masa itu anak(Pangeran Amir, Pangeran Rahmat dan Pangeran Abdullah) dari Sultan Tahmidillah I masih belum terbilang cukup umur untuk menjadi pemimpin. Namun kemudian terjadi perebutan tahta akibat campur tangan dan adu domba dari Belanda pada kaum Bangsawan yang ada di keraton Martapura. Sehingga menyebabkan terbunuhnya Pangeran Rahmat dan Pangeran Abdullah karena pembunuhan. Kemudian Belanda membawa minuman keras sehingga dapat membuat keluarga kerajaan menjadi berubah seperti seringnya berfoya- 
foya/mabuk dan lupa bahwa dalam islam dilarang. Sehingga suatu hari Pangeran Antasari melihat peristiwa tersebut membuat sangat mual karena dengan kondisi yang terjadi, dapat membuat runtuhnya kerajaan Banjar.

\section{PERJUANGAN PANGERAN ANTASARI}

Pada masa ini nama dari Pangeran Antasari tidak dapat dipisahkan dari Pangeran Hidayat sampai pertentangan dengan Pangeran Tamjid. Sehingga Pangeran Antasari keluar dengan aura wibawanya dan membawa pengaruh yang sangat besar sebagai Pahlawan. Kemudian meletusnya perang Banjar atau nama lainnya "Banjarmasinsche krijg" berlangsung pada tahun 1859 dan berakhir pada tahun 1905 sampai yang dimana terbunuhnya raja banjar yang terakhir yaitu Sultan Muhammad Seman. Sehingga belanda menyimpulkan bahwa dengan terbunuhnya Sultan Muhammad Seman berarti selesai sudah perang banjar terhadap koloni Belanda. Namun dalam berlangsungnya perang banjar selama 46tahun tersebut terjadi dipenuhi dengan pengorbanan dan derita masyarakat Banjar.

Pangeran Antasari yang mendalam ia aktif berdakwah. karena memiliki ilmu agama pada kondisi sambil berperang serta menyebarkan agama islam di daerah yang pernah disinggahi. Para masyarakat di Hulu Sungai Barito sebagai bukti yang menjadi muslim serta memberikan dukungan terhadap perjuangan Pangeran Antasari dalam melawan Belanda. Kemudian Pangeran Antasari juga melakukan Akulturas\&Asimilasi dengan menikahkan anaknya maupun cucunya dengan suku Dayak. Sehingga terciptalah persatuan antara Suku Dayak dengan Banjar yang tidak dapat terpisahkan.

Kemudian Pihak Belanda menyatakan "perang kemerdekaan atau perang banjar disebabkan oleh rakyat banjar yang tidak suka melihat diangkatnya Pangeran Tamjid menjadi pemimpin kerajaan. Namun belanda berpura-pura bahwa perang tersebut perang penuh perjuangan dalam mengusir kolonial belanda yang mau menguasai tanah airnya yaitu Banjar” (Antemas, 2004: 57-58). Memang dapat diakui bahwa calon pemimpin kerajaan ada Pangeran Tamjid(yang sangat dekat dengan belanda), Pangeran hidayat(yang berjiwa seni tetapi tidak mempunyai kemampuan memerintah) dan Prabu Anom(banyak dukungan dikalangan istana namun tidak mempunyai wibawa untuk 
memimpin negeri). Kemudian Van Hest ikut campur dalam permasalahan tersebut dengan membantu mengangkat Pangeran Tamjid menjadi pemimpin kerajaan, kemudian mangkubminya Pangeran Hidayat. Namun Prabu Anom dijadikan tahanan dengan kategori tahanan Kota banjarmasin.

Sehingga terjadi perpecahan besar terjadi pemberontakan disana-sini lalu muncul perintah untuk Pangeran Hidayat sebagai mangkubumi untuk meredakan pemberontakan tersebut. Namun ketika sampai di daerah tersebut diketahui bahwa yang memimpin dalam pemberontakannya adalah Pangeran Antasari yang merupakan saudara sepupunya. Sehingga Pangeran Hidayat beralih atau memihak ke Pangeran Antasari dengan membawa pasukan dari Muning(margasari) untuk menyerang benteng Belanda di Pengaron yang berjumlah 3000orang yang merupakan rakyat. Namun disana banyak korban yang gugur dalam pemberontakan tersebut.

Kemudian melahirkan pejuang dan patriot gagah berani seperti Demang Lehman(Martapura), Tumenggung Surapati(Muara Teweh), Tumenggung Jalil(Amuntai), Tumenggung Naro(Baruh-Bahino), Panglima Batur(Marabahan), dan Penghulu Rasyid(kalua). Perang Banjar yang dikobarkan bukan hanya perang biasa, Cuma kata-kata dan rencana saja. Tapi, terjadi karena perbuatan Belanda di Kenyataan yang kemudian membuat medan perang menjadi semakin luas dari Martapura, Pelaihari, Hulu Sungai, sepanjang kali Barito sampai pelosok Kahayan. Pangeran Antasari menyatukan perjuangan rakyat(sampai suku Dayak) yang bertujuan sama yaitu melawan dan menentang kolonial belanda karena ingin menguasai kerajaan Banjar sekaligus dengan rakyat Banjar.

Pemberontakan semakin bertambah sampai pelosok KalSel serta KalTeng akibat Pangeran Tamjid menyerahkan kerajaan pada 25 Juni 1859 dengan sepenuhnya kepada Belanda yang kemudian tanggal 16 Juli 1859 pangeran Tamjid diasingkan dipulau Jawa oleh Belanda. Pada bulan Oktober 1860 benteng Batumandi dipertahankan oleh Pangeran Antasari didampingi oleh Angka Wijaya yang merupakan wanita terkenal karena kesetiaan dan kegigihannya dalam perang (Antemas, 2004: 60-61). Pada suatu hari banyak rakyat Banjar dan Suku Dayak terutama Suta Ono yang merupakan kepala suku Dayak Maanyan dan Temanggung Jaya Negara kepala suku dari Dayak Ngaju 
terpaksa berpihak dengan Belanda dan memilih berkhianat dengan perjuangan rakyat karena tekanan yang cukup kuat dari pihak Belanda terhadap rakyat banjar.

Sehingga Pangeran Antasari dan Pengikutnya menghadapi tekanan yang berat dari saudara seagama bahkan sampai saudara sebangsa(suku Dayak, Bugis, Kutai) berada dibawah pengaruh dan genggaman Belanda. Walaupun Pangeran Antasari mendapat dukungan dari para ulama dan tokoh agama dengan berhasil dibangkitkannya pasukan Beratib. Yang kemudian memang perang tak hanya membutuhkan dalam keterbatasan senjata akan tetapi juga memprioritaskan pendekatan Spiritual (Barjie B, 2013: 115).

Dalam pertempurannya Pangeran Antasari menjalin kerjasama dengan beberapa Tokoh Dayak di hulu sungai barito. Sehinnga tidak hanya berperang dijalur darat akan tetapi di sungai/laut. Kotamara yang merupakan nama benteng rakit apung yang dibuat oleh para pejuang yang dikendarai oleh suku Dayak di pulau Kanamit, Sungai Barito pada 6 Agustus 1859. Kemudian 22 Februari 1860 terjadi pengepungan pada Benteng Leogong sehingga Tumenggung Surapati dan Pangeran Antasari menggunakan strategi mundur untuk menghindar dari korban yang berjatuhan sehingga membuat Belanda tidak puas terhadap peristiwa tersebut.

Dengan perhitungan yang matang dengan siasat perang maka markas besar dipindahkan ke Barito karena terlihat dapat menguntungkan untuk pertempuran selanjutnya. Sehingga Barito dikatakan daerah yang penting dalam sejarah. Setelah 11 hari Pangeran Hidayat diasingkan yaitu Pada 14 Maret 1862. Maka Pangeran Antasari Diangkat menjadi Pimpinan tertinggi diKerajaan Banjar dengan gelar panembahan “Khalifatul Mu'minin” dengan mengikrarkan prinsip teguh yang berbunyi "Hidup untuk Allah dan Mati untuk Allah”. Yang kemudian ditanda tangani oleh Tumenggung Surapati WD(Wakil Daerah) Barito, Raden Mas Warga Natawijaya WD Teweh dan Tumenggung Mangkusari WD Kahayan/Kapuas. Pangeran Antasari pengangkatan serta kemudian mendapat 3 jabatan karena dipercaya dalam perjuangannya dari segi kerohaniannya maupun segi kebendaan diantaranya yaitu Panglima tertinggi dalam perang maupun pertahanan, kepala pemerintahan Negara dan kepala Agama Tertinggi.

Berulang kali Belanda mengajak kompromi Pangeran Antasari namun selalu gagal. Karena ia tahu hal tersebut hanyalah siasat busuk Belanda untuk menangkapnya. Hal 
tersebut dapat diketahui karena ia melihat dari sejarah perundingan yang diadakan Belanda dengan Pangeran Diponegoro yang kemudian ditangkap saat perundingan berlangsung. Kejadian tersebut terjadi karena Belanda hanya berpura-pura berunding dengan musuhnya. Belanda pernah mengadakan sayembara yaitu seperti "barang siapapun yang bisa membawa pangeran Antasari dengan hidup maupun mati akan diberikan f. 10.000" namun hasilnya hanya sia-sia saja.

\section{SAAT TERAKHIR PANGERAN ANTASARI}

Dengan perjuangan yang panjang dilakukan oleh Pangeran Antasari kemudian pada akhirnya mengambil pilihan "lebih baik meninggal dimedan perang daripada binasa di penjara musuh(Belanda)". Sehingga sekian lama aktif berperang tiba dimana kondisi Pangeran Antasari Jatuh sakit apalagi ia sudah relatif hampir berumur 60 tahun namun dengan kondisi seperti itu juga Pangeran Antasari tetap tidak pernah mau untuk menyerah ataupun berunding dengan Belanda. Pada saat bersamaan juga ia membagikan tugas masing-masing kepada anaknya yang bernama Gusti Muhammad Seman serta Pahlawan lainnya untuk menjaga benteng rakyat disekitar Barito.

Kemudian Pada 11 Oktober 1862 merupakan hari duka yang paling bersejarah karena telah berpulang kerahmatullah dengan kondisi sakit Pangeran Antasari yang memegang gelar "Panembahan Amiruddin Khalifatul Mu'minin". Jenazah beliau dimakamkan di kampung Sampirang, Bayan Begok, Puruk Cabu yang dimana masyarakat Banjar datang berziarah. Akan tetapi pada saat Indonesia merdeka pada 11 November 1958 jenazahnya dipindahkan yang pada saat bersamaan sebagian masyarakat Dayak menyaksikan penggalian kembali menangis sedih karena mereka sudah menganggap Pangeran Antasari sebagai pemimpin suku Dayak serta Sultan Banjar. Dan kemudian kembali makamkan dimakam Pahlawan Banjar(dekat Masjid Jami’ Banjarmasin) bersama jenazah Isteri beliau.

Kemudian setelah sepuluh tahun setelah pemindahan makamNya beliau mendapat gelar Pahlawan Nasional melalui surat keputusan Presiden RI Nomor 95/TK/1968 bertanggal 27 Maret 1968. Beliau merupakan Pahlawan Nasional yang pertama dari Banjar. Karena atas jasa-jasanya ketika Perang banjar berlangsung. 


\section{SIMPULAN}

Pangeran Antasari merupakan Raja Banjar yang lahirnya di perkirakan sekitar tahun 1790 di kampung yang dikenal Sungai Batang, Martapura. Beliau merupakan anak dari keturunan bangsawan Banjarmasin yaitu Pangeran Mas'ud(Masohot) merupakan Ayahnya dan Mas Teroda merupakan Ibunya. Walau ia adalah keturunan bangsawan ia memiliki sifat sopan santun dalam pergaulan dan watak yang rendah hati. Kemudian akibat pengetahuan tentang agama islam kelak akan diangkat oleh rakyat yaitu menjadi "khalifatul Mu'minin" karena sering menuntut ilmu agama islam disela waktu luang.

Pada 14 Maret 1862 yaitu setelah 11 hari Pangeran Hidayat diasingkan. Maka Pangeran Antasari Diangkat menjadi Pimpinan tertinggi diKerajaan Banjar dengan gelar panembahan "Khalifatul Mu'minin" dengan mengikrarkan prinsip teguh yang berbunyi "Hidup untuk Allah dan Mati untuk Allah". Yang kemudian ditanda tangani oleh Tumenggung Surapati WD(Wakil Daerah) Barito, Raden Mas Warga Natawijaya WD Teweh dan Tumenggung Mangkusari WD Kahayan/Kapuas. Pangeran Antasari pengangkatan serta kemudian mendapat 3 jabatan karena dipercaya dalam perjuangannya dari segi kerohaniannya maupun segi kebendaan diantaranya yaitu Panglima tertinggi dalam perang maupun pertahanan, kepala pemerintahan Negara dan kepala Agama Tertinggi.

Kemudian Pada 11 Oktober 1862 merupakan hari duka yang paling bersejarah karena telah berpulang kerahmatullah dengan kondisi sakit Pangeran Antasari yang memegang gelar "Panembahan Amiruddin Khalifatul Mu'minin". Jenazah beliau dimakamkan di kampung Sampirang, Bayan Begok, Puruk Cabu yang dimana masyarakat Banjar datang berziarah. Akan tetapi pada saat Indonesia merdeka pada 11 November 1958 jenazahnya dipindahkan yang pada saat bersamaan sebagian masyarakat Dayak menyaksikan penggalian kembali menangis sedih karena mereka sudah menganggap Pangeran Antasari sebagai pemimpin suku Dayak serta Sultan Banjar. Dan kemudian kembali makamkan dimakam Pahlawan Banjar(dekat Masjid Jami’ Banjarmasin) bersama jenazah Isteri beliau. 


\section{REFERENSI}

Antemas A. (2004). ORANG-ORANG TERKEMUKA DALAM SEJARAH KALIMANTAN. ANANDA NUSANTARA.

Barjie B A. (2013). Tokoh Banjar Dalam Sejarah (Antara Legenda dan Kisah Nyata) cet. I. Banjarmasin: CV. Rahmat Hafiz Al Mubaraq.

Barjie B A. (2016). Perang Banjar Barito (1859-1906). Banjarmasin: Pustaka Agung Kesultanan Banjar.

Handy, M. R. N. (2021). Pembelajan Sejarah Dalam Membangun Historical Awarness dan Sikap Nasionalisme Pada Peserta Didik. Prabayaksa: Journal of History Education, 1(1), 49-54.

Handy, M. R. N., \& Fatimah, S. N. (2019). Biography of Syekh Muhammad Nafis AlBanjari: An Investigation of Value in the Spread of Islam as a Learning Source on Social Studies. The Kalimantan Social Studies Journal, 1(1), 40-50.

Hasanah, H. (2016). Pendidikan Islam Pada Masa Kerajaan Banjar (Abad ke-18).

Ningrum, A. O. C. (2015). Analisis Pengamen Jalanan Di Kota Surakarta (Studi kasus Pengamen Jalanan di Kota Surakarta) (Doctoral dissertation, Universitas Muhammadiyah Surakarta). 